\section{Dipeptidylpeptidase-IV, a key enzyme for the degradation of incretins and neuropeptides: activity and expression in the liver of lean and obese rats}

\author{
E. Tarantola, ${ }^{1}$ V. Bertone, ${ }^{1}$ G. Milanesi, ${ }^{1}$ \\ E. Capelli, ${ }^{2}$ A. Ferrigno, ${ }^{3}$ D. Neri, ${ }^{4}$ \\ M. Vairetti, ${ }^{3}$ S. Barni, ${ }^{1}$ I. Freitas ${ }^{1,5}$ \\ 'Department of Biology and \\ Biotechnology “Lazzaro Spallanzani”, \\ University of Pavia; \\ 2Department of Sciences and \\ Technologies for the Environment, \\ University of Pavia; \\ ${ }^{3}$ Department of Internal Medicine and \\ Therapeutics, University of Pavia; \\ 4Surgical and Gastroenterological \\ Department, Hepatobiliary Surgery and \\ Liver Transplant Unit, University of \\ Padua;
}

Institute of Molecular Genetics of CNR, Histochemistry and Cytometry Section, Pavia, Italy

\section{Abstract}

Given the scarcity of donors, moderately fatty livers (FLs) are currently being considered as possible grafts for orthotopic liver transplantation (OLT), notwithstanding their poor tolerance to conventional cold preservation. The behaviour of parenchymal and sinusoidal liver cells during transplantation is being studied worldwide. Much less attention has been paid to the biliary tree, although this is considered the Achille's heel even of normal liver transplantation. To evaluate the response of the biliary compartment of FLs to the various phases of OLT reliable markers are necessary. Previously we demonstrated that Alkaline Phosphatase was scarcely active in bile canaliculi of FLs and thus ruled it out as a marker. As an alternative, dipeptidylpeptidase-IV (DPPIV), was investigated. This ecto-peptidase plays an important role in glucose metabolism, rapidly inactivating insulin secreting hormones (incretins) that are important regulators of glucose metabolism. DPP-IV inhibitors are indeed used to treat Type II diabetes. Neuropeptides regulating bile transport and composition are further important substrates of DPP-IV in the enterohepatic axis. DPP-IV activity was investigated with an azo-coupling method in the liver of fatty Zucker rats ( $f a / f a$ ), using as controls lean Zucker ( $f a /+)$ and normal Wistar rats. Protein expression was studied by immunofluorescence with the mono- clonal antibody (clone 5E8). In Wistar rat liver, DPP-IV activity and expression were high in the whole biliary tree, and moderate in sinusoid endothelial cells, in agreement with the literature. Main substrates of DPP-IV in hepatocytes and cholangiocytes could be incretins GLP-1 and GIP, and neuropeptides such as vasoactive intestinal peptide (VIP) and substance $P$, suggesting that these substances are inactivated or modified through the biliary route. In lean Zucker rat liver the enzyme reaction and protein expression patterns were similar to those of Wistar rat. In obese rat liver the patterns of DPP-IV activity and expression in hepatocytes reflected the morphological alterations induced by steatosis as lipid-rich hepatocytes had scarce activity, located either in deformed bile canaliculi or in the sinusoidal and lateral domains of the plasma membrane. These findings suggest that bile canaliculi in steatotic cells have an impaired capacity to inactivate incretins and neuropeptides. Incretin and/or neuropeptide deregulation is indeed thought to play important roles in obesity and insulin-resistance. No alteration in enzyme activity and expression was found in the upper segments of the biliary tree of obese respect to lean Zucker and Wistar rats. In conclusion, this research demonstrates that DPPIV is a promising in situ marker of biliary functionality not only of normal but also of fatty rats. The approach, initially devised to investigate the behaviour of the liver during the various phases of transplantation, appears to have a much higher potentiality as it could be further exploited to investigate any pathological or stressful conditions involving the biliary tract (i.e., metabolic syndrome and cholestasis) and the response of the biliary tract to therapy and/or to surgery.

\section{Introduction}

The increased demand of organs for orthotopic liver transplantation (OLT) has stimulated the research of strategies to expand the pool of donors by including the so-called marginal organs, especially fatty livers (FLs). In the traditional methods of transplantation organs are first submitted to a cold ischemic preservation period, known as cold storage (CS), followed by warm reperfusion with an oxygenated medium. Steatotic livers are much more susceptible to the cold preservation and reperfusion steps, and in particular to oxidative stress, respect to normal organs; they show loss of viability of sinusoidal endothelial cells, sinusoidal congestion and rupture of hepatocytes with release of fat droplets, causing microcirculatory failure ${ }^{1,2}$ and are prone to Primary Non Function or to Initial Poor
Correspondence: Prof. Isabel Freitas, Laboratory of Comparative Anatomy and Cytology, Department of Biology and Biotechnology, via Ferrata 9, 27100 Pavia, Italy.

Tel. +39.0382 .986317 - Fax: +39.0382 .986406 .

E-mail: freitas@unipv.it

Key words: Dipeptidylpeptidase-IV, fatty liver, incretins, neuropeptides, biliary tree, bile canaliculi, hepatocytes.

Acknowledgements: the authors are very grateful to the anonymous reviewer for valuable comments and suggestions to improve the immunohistochemical determinations and the discussion of the results. They would also like to thank Mr. Gaetano Viani for his skilful technical assistance. The techniques described in this manuscript are being currently applied to the Research Program "Real time monitoring of liver oxidative stress injuries by means of innovative methodology based on integrated autofluorescence optical biopsy. Application to transplantation procedure" (ref. 2011-0439), financed by Fondazione Cariplo. The research was supported by MIUR-PRIN (Ministero dell'Università e Ricerca, Progetti di Rilevante Interesse Nazionale) 2004 and 2006 and by F.A.R. (Fondi di Ateneo per la Ricerca), University of Pavia, Italy.

Contributions: IF, study conception and design; VB, ET, GM, tissue preparation morphology, enzyme and immunohistochemical analyses; $\mathrm{MV}$, $\mathrm{AF}, \mathrm{DN}$, expertise on fatty liver and liver transplantation; SB, EC, expertise on liver morphology and functionality. All authors: data analysis and interpretation contribution; IF, VB, ET, final manuscript writing. VB, ET, contributed equally to the present work.

Conflict of interests: the authors declare no conflict of interests.

Received for publication: 21 December 2011. Accepted for publication: 26 July 2012

This work is licensed under a Creative Commons Attribution NonCommercial 3.0 License (CC BYNC 3.0).

(C) Copyright E. Tarantola et al., 2012 Licensee PAGEPress, Italy

European Journal of Histochemistry 2012; 56:e41 doi:10.4081/ejh.2012.e41

Function after reimplantation. ${ }^{3-7} \mathrm{~A}$ further effect of steatosis is the development of posttransplant ischemic-type biliary lesions. ${ }^{8}$ Even for normal organs the biliary tree is known as the Achille's heel of OLT. ${ }^{9-13}$ The formation of bile depends on the structural and functional integrity of the biliary tree and its impairment results in cholestasis. Early changes in bile 
composition are believed contribute to the relatively late stricturing of the large bile ducts. ${ }^{14}$ The different cell types of the biliary tree (hepatocytes, transition cells of Hering canals and cholangiocytes of small and large bile ducts) play different roles in the progressive post-transplantation injury phases to the biliary tract. Bile formation indeed depends on the structural and functional integrity of all the component of the biliary tree.

The rapid resume of biliary secretion is an important index of hepatic functional restoration after preservation by CS. ${ }^{15}$ The analysis of the behaviour of the biliary tree during the various phases of transplantation has however lagged behind studies concerning hepatocytes and sinusoidal cells even though bile canaliculi are damaged markedly and early during ischemia-reperfusion occurring in patients undergoing OLT. ${ }^{16}$ Furthermore, the damage to bile duct cells is important in the long-lasting phase of reperfusion injury ${ }^{17}$ and the recovery of the biliary tree from preservation injury takes longer compared with hepatocytes or endothelial cells. ${ }^{18}$ A single study has related the degree of steatosis to the risk of post-transplantation biliary complications, suggesting that the impaired sinusoidal microcirculation could be responsible of the ischemic damage to the biliary tree. ${ }^{8}$ To the best of our knowledge, no study addressed the role of the various compartments of the biliary tree of FLs in the altered production of bile. An adequate histochemical marker is thus necessary to monitoring the functionality and possible alterations of the biliary tree of FL induced by OLT. This is particularly true since the urge to use livers with low-to-moderate steatosis as donors has stimulated the search for modalities of preservation alternative to $\mathrm{CS}$. Machine Perfusion at subnormothermic temperature $\left(20^{\circ} \mathrm{C}\right), \mathrm{MP} 20$, is a modality developed by our group that appears as a promising strategy to protect the liver of normal and obese rats. ${ }^{19-22}$ The better response of fatty livers to MP20 than to CS was evaluated in terms of morphology, enzyme release into the perfusate and the bile, energy charge, glycogen content, production of reactive oxygen species (ROS), TNF- $\alpha$ production and apoptosis. ${ }^{19-23}$ For the evaluation of the response of the biliary tree of fatty livers to these two preservation modalities a specific marker was sought.

A common index of injury to the biliary tree, also evaluated by our group, ${ }^{20}$ is Alkaline Phosphatase (AlkPh; EC 3.1.3.1). However, AlkPh demonstrated to be inactive in bile canaliculi of FL and was therefore discarded. ${ }^{24}$ As an alternative, we investigated the activity and expression of a further known marker of the biliary tree, Dipeptidylpeptidase-IV (DPPIV; EC 3.4.14.5), otherwise known as adenosine deaminase complexing protein 2
(ADAbp2), CD26 (cluster of differentiation $26)^{25}$ or T cell activation protein. ${ }^{26-28}$ Several histochemical studies to demonstrate the activity of DPP-IV in normal liver with the azocoupling technique have been made in the past. $^{29-32}$

To the best of our knowledge, the only paper mentioning DPP-IV activity evaluated in situ in steatotic hepatocytes regarded biopsies from livers of patients with hepatocellular carcinoma. ${ }^{33}$ No histochemical study has been performed on DPP-IV activity and expression in the liver of obese animals notwithstanding the fact that a histochemical approach would have been particularly useful to follow the response of the liver to the various DPP-IV pharmacological inhibitors currently being tested for Type 2 diabetes $^{34-37}$ and for diabetes-associated obesity and steatosis. ${ }^{38,39}$ Inhibition of DPP-IV indeed increases insulin secretion and reduces glucagon secretion by preventing the inactivation of glucagon-like peptide-1 (GLP1), thereby lowering glucose levels..$^{38,39}$ It has been recently suggested that DPP-IV may play a role in the progression of non-alcoholic fatty liver disease (NAFLD); in particular, increased hepatic expression of DPP-IV in NAFLD may be associated with metabolic factors, including insulin resistance, and may adversely affect glucose metabolism in this liver disease..$^{40}$ Furthermore, several DPP-IV substrates are implicated in the pathogenesis of NonAlcoholic Steatohepatitis (NASH) ${ }^{38}$

DPP-IV is an integral membrane type II glycoprotein that plays a dual role as a regulatory serine exopeptidase and as a binding protein. DPP-IV has a post-proline dipeptidyl aminopeptidase activity, preferentially cleaving Xaa-Pro or Xaa-Ala dipeptides (where Xaa is any amino acid) from the $\mathrm{N}$-terminus of polypeptides. The presence of proline residues at the penultimate position in their $\mathrm{N}$-terminal is an evolutionary conserved strategy protecting several biologically active peptides from general proteolytic attack. ${ }^{41}$ DPP-IV behaves as a multifunctional protein. Its substrates include: i) neuropeptides (e.g., neuropeptide Y; endomorphin; substance P; bombesin/gastrinreleasing peptide); ${ }^{25,34,42-47}$ ii) peptide hormones (e.g. peptide YY; VIP; growth hormonereleasing hormone (GHRH), also known as growth-hormone-releasing factor (GRF, GHRF), somatoliberin or somatocrinin; glucagon; glucagon-like peptides 2 (GLP-2); secretin; enkephalin; ${ }^{25,34,42-48}$ iii) incretins such as glucagon-like peptide-1 (GLP-1), gastric inhibitory polypeptide (GIP; also known as glucose-dependent insulinotropic peptide); ${ }^{25,34,42-47}$ iv) paracrine chemokines like RANTES (Regulated on Activation Normal Tcell Expressed and Secreted; CCL5), stromal cell-derived factor, eotaxin (CCL11) and macrophage-derived chemokine (MDC), inter- feron-inducible chemokines and other chemokines involved with inhibition of HIV infection; ${ }^{26}$ (5) fibrinogen a-chain.

The protein DPP-IV also has non-enzymatic roles and in particular it acts as a ligand, interacting with several other proteins such as adenosine deaminase (ADA), HIV gp120 protein, collagen, chemokine receptor CXCR4. ${ }^{49,50}$ Further ligands are proteins involved in plasmin activation, ${ }^{34} \mathrm{Na}^{+} / \mathrm{H}^{+}$ion exchanger 3 (NHE3), ${ }^{51}$ fibronectin and tyrosine phosphatase CD45. ${ }^{45,49,50}$ DPP-IV (CD26)-protein interactions are involved in immune function, ion transport, regulation of cell binding to the extracellular matrix and cell-cell signalling. ${ }^{45,49,50}$ Multifunctional proteins such as this are also called moonlighting proteins..$^{44,52,53}$ In addition to the integral membrane form, a soluble, truncated form of DPP-IV (sCD26) occurs in serum and other body fluids. ${ }^{42}$ The change in serum DPP-IV level is associated with autoimmune diseases, infections, cancers, depression and also liver diseases. ${ }^{50}$

DPP-IV is expressed by capillary endothelial cells and activated lymphocytes and on apical surfaces of epithelial, including acinar, cells. DPP-IV is present in particular in the gastrointestinal tract, biliary tract (including bile canaliculi), exocrine pancreas, kidney, thymus, lymph node, uterus, placenta, prostate, adrenal, parotid, sweat, salivary and mammary glands and endothelia of all organs examined, including liver, spleen, lungs and brain. ${ }^{34}$ In the enterohepatic axis, the role of DPP-IV is particularly linked to the catabolism of neuropeptides and incretins regulating glucose metabolism and food intake. ${ }^{42,47,54}$ Substance P, for instance, involved in the modulation of pain, also stimulates the contraction of smooth muscle fibers of veins and intestine. Peptide YY, similar to neuropeptide Y, is stimulated by the presence of glucose, lipids, fat acids and bile salts in the intestinal lumen. Its functions are: acid secretion and gastric filling, pancreatic exocrine and insulin endocrine secretion. Its release is induced by cholecystokinine (CCK), VIP and by the incretin glucagon-like peptide-1 (GLP-1); it is inhibited by DPP-IV that cuts its $\mathrm{N}$-terminus with proline. Incretins are hormone-like substances that control insulin secretion by pancreatic $\beta$-cells after meal anticipating the rise in blood glucose. The incretins GLP-1 and glucose-dependent insulinotropic polypeptide (GIP) are inactivated by DPP-IV. GLP-1 and GIP enhance glucosedependent insulin secretion and modulate nutrient passage from the gastrointestinal tract to appropriate tissue stores. ${ }^{55,56}$ GLP-1 secretion is reduced in patients with Type 2 diabetes and in obese subjects. ${ }^{57}$

Obese Zucker rats (ZR) are frequently used as models of obesity and insulin-resistance. ${ }^{58,59}$ The obese ZR are homozygous for non-func- 
tional leptin receptors $(f a / f a) ;{ }^{60,61}$ they thus cannot respond to the satiety stimulus and became hyperphagic, obese, hyperinsulinemic (insulin-resistant) but have normal blood glucose levels and do not develop diabetes. ${ }^{62}$ Lean ZR that are heterozygous for the allele fa $(f a /+)$ maintain a lean phenotype throughout life with normal blood insulin and glucose levels. We investigated DPP-IV activity and expression in the liver of obese ZR. As controls, we used either lean ZR (the usual control for obese ZR) and normal Wistar rats that do not present the mutation. Here, we demonstrate that the activity and expression of DPPIV in the biliary tree of obese ZR liver is similar to that of normal Wistar rat liver from Hering canals to bile ducts whereas it is altered at canalicular level, especially in fatty hepatocytes.

\section{Materials and Methods}

\section{Chemicals}

Unless otherwise stated, all reagents were of the highest purity grade available and were purchased from Sigma (Milan, Italy).

\section{Animals}

Male Wistar rats (250-300g) (Harlan-Nossan, Corezzana, Italy), 11-12 week old obese ( $f a / f a)$ $(375 \pm 15 \mathrm{~g})$ and lean $(f a /+)(300 \pm 10 \mathrm{~g})$ male Zucker rats (Charles River, Calco, LC, Italy) were used. The animals were allowed free access to water and food in all the experiments. The use and care of animals in this experimental study was approved by the Italian Ministry of Health and by the University Commission for Animal Care. Rats were anesthetized with sodium pentobarbital (40 mg/kg i.p.).

\section{Morphology}

Liver samples were quickly removed, and small fragments were fixed by immersion in $2.5 \%$ glutaraldehyde in $0.13 \mathrm{M}$ Millonig buffer (pH 7.2-7.4) at $4^{\circ} \mathrm{C}$ for $4 \mathrm{~h}$, rinsed, post-fixed with $1 \%$ osmium tetroxide at $4^{\circ} \mathrm{C}$ for $2 \mathrm{~h}$, washed, dehydrated through graded concentrations of alcohol, and embedded in Epon. Semithin sections ( $1 \mu \mathrm{m}$ thick) were stained with $1 \%$ Toluidine Blue. For the demonstration of the enzyme activity and expression of DPP-IV small tissue blocks were cut, inserted in cryovials and snap-frozen immediately in liquid nitrogen, then kept at $-80^{\circ} \mathrm{C}$ until use. Cryostat sections, $8 \mu \mathrm{m}$ thick, were cut at $-24^{\circ} \mathrm{C}$ on a Leica CM 1850 cryostat. The sections were fixed, for both determinations, first in cold acetone $\left(4^{\circ} \mathrm{C}\right)$ for $5 \mathrm{~min}$, then in cold ethanol $95 \%$ $\left(4^{\circ} \mathrm{C}\right)$ for $5 \mathrm{~min}$ and air-dried for $5 \mathrm{~min}$ at room temperature.

\section{Demonstration of DPP-IV enzyme activity}

Simultaneous azo-coupling method ${ }^{63}$ was performed on fixed cryosections by incubation at $37^{\circ} \mathrm{C}$ for 30 min with a medium containing:

- PVA (polyvinyl alcohol) 18\% in Trismaleate buffer $0.1 \mathrm{M} \mathrm{pH} 8$

- Gly-Pro-methoxy- $\beta$-naphthylamide 1mM

- NaCl 100 mM

- Fast Blue BB 2mM

To stop the reaction and to remove the incubation medium the sections were rinsed with hot $\left(45-50^{\circ} \mathrm{C}\right)$ tap water and the slide mounted with glycerine-jelly. Control reaction was performed in the absence of substrate and with the selective competitive inhibitor Diprotin-A (Ile-Pro-Ile). ${ }^{32,42}$

With the azo-coupling method employed the activity of DPP-IV is demonstrated by a orangered final reaction product.

\section{Demonstration of DPP-IV expression}

In order to block aspecific binding of antibodies and fluorochrome, fixed cryosections were pre-incubated for $30 \mathrm{~min}$ at room temperature in Phosphate Buffered Saline solution (PBS) containing 10\% normal goat serum, 3\% bovine serum albumin (BSA) and 1,5\% NaCl. Sections were then incubated in the dark for $1 \mathrm{~h}$ at room temperature with the primary monoclonal antibody mouse anti-rat CD26/DPP-IV (5E8 clone) (Santa Cruz Biotechnology, Santa Cruz CA, USA) diluted 1:150 in a Phosphate Buffered Saline solution (PBS) containing $10 \%$ normal goat serum, $3 \%$ bovine serum albumin (BSA) and 1,5\% NaCl. The slides were then rinsed twice for $5 \mathrm{~min}$ in a PBS solution containing $0,2 \%$ Triton- $X$ and once for $5 \mathrm{~min}$ in PBS. The sections were hence incubated for 30 min in the dark at room temperature with the secondary antibody, Alexa Fluor® 594 Goat Anti-Mouse IgG $(\mathrm{H}+\mathrm{L})$ (Invitrogen Molecular Probes) diluted 1:700 in PBS. Afterwards, the sections were rinsed 3 times for 5 min in PBS containing $0.2 \%$ Triton-X. Control reactions, made by replacing the primary antibody with PBS, were completely negative.

\section{Microscopy and photomicrography}

The slides were observed with Zeiss Axioskop 2 Plus light microscope (Carl Zeiss Microimaging, Jena, Germany) equipped with Differential Interference Contrast (DIC) system. A triple filter set 61.002 (DAPI/FITC/Texas Red Chroma Tecnnology Corporation, USA) was used to document immunofluorescence.

\section{Results}

\section{Wistar rat liver}

Enzyme activity

As illustrated in Figure 1, strong DPP-IV activity was present in all the segments of the biliary tree. The activity in bile canaliculi reflected their typical chicken-wire pattern (Figure $1 \mathrm{c}, \mathrm{d}$ ) and was not zonated from periportal (P) to centrolobular (CL) areas (Figure 1a). In Hering canals staining was intense in the cytoplasm and plasma membrane (Figure 1 b,c). In small bile duct (d) the activity was present in the apical pole (Figure 1c) whereas in larger duct (D) it was seen in the apical and lateral domains of the plasma membrane (Figure 1b). Medium-low enzyme activity was also present in the cytoplasm of endothelial cells of some (but not all) sinusoids (arrowheads) (Figure $1 \mathrm{c}, \mathrm{d}$ ). Strong activity was noticed in the endothelium of some, but not all, portal arteries. The reaction was totally inhibited by Diprotin A (Ile-Pro-Ile) (not shown).

Protein expression demonstrated with immunofluorescence

As shown in Figure 2, the patterns of red fluorescence entirely reflect the activity of the enzyme both in the biliary tree and in sinusoidal endothelial cells.

\section{Liver from lean and obese Zucker rats}

In Figure 3 the morphology of lean and obese Zucker rat liver, assessed from semithin sections stained with Toluidine Blue, is compared. Lean ZR liver (Figure 3a) showed a normal morphology with almost lipid-free hepatocytes, rich in glycogen stores and mitochondria. Bile canaliculi, observed in longitudinal and transversal sections, showed the typical distribution. The morphology of these livers is similar to that of Wistar rat liver (not shown). In obese ZR liver (Figure 3b), bile canaliculi were identified only in periportal hepatocytes. By contrast, canaliculi were not visible in the steatotic areas where they were likely hidden or distorted by lipid droplets. Both microsteatotic and macrosteatotic hepatocytes were identified. Most macrosteatotic hepatocytes showed unstained lipid droplets presumed to be of saturated lipid unfixed by $\mathrm{OsO}_{4}$; a few droplets of unsaturated lipids were also observed.

\section{Enzyme activity on lean Zucker rat liver}

As shown in Figure 4 a,b, the DPP-IV enzyme activity in lean Zucker rat liver was similar to that observed in the liver of Wistar rats (Figure 1). 
Enzyme activity of obese Zucker rat liver

As illustrated in Figure $5 \mathrm{a}$,b, the patterns of DPP-IV activity in hepatocytes reflected the morphological alterations induced by steatosis, especially in the MZ. The reaction was very intense and presented a typical chicken-wire pattern in bile canaliculi of normal hepatocytes (Figure 5c) whereas most macrosteatotic hepatocytes, abundant in the midzone (MZ), had scarce activity, located either in deformed bile canaliculi or in the sinusoidal and lateral domains of the plasma membrane (Figure 5 a,b,d). No significant differences respect to Wistar and lean ZR liver were seen as Hering canals (Figure 5d), small bile ducts (Figure 5d) and large bile ducts (not shown) are concerned. Respect to Wistar and lean ZR liver, lower cytoplasmic enzyme activity was present in sinusoidal endothelial cells (arrowheads) (Figure 5c).

\section{Protein expression}

The expression of DPP-IV in lean rat liver (Figure 6a) corresponds to the enzyme activity shown in Figure 4. The expression in obese rat liver (Figure 6b), as the enzyme activity (Figure 5), supports the gross alteration of the bile canaliculi network in these animals.

\section{Discussion}

The bile secretion plays unique and critical role in liver physiology, since bile serves as a vehicle for the secretion of bile acids or bile salts that are essential for the intestinal digestion of lipids and assimilation of lipid-soluble nutrients. It is also involved in excretion of potentially toxic material including cholesterol, bilirubin, and of a wide range of xenobiotics such as drugs and environmental chemicals and their metabolites ${ }^{64,65}$ Bile is produced by hepatocytes and is modified by cholangiocytes lining the bile ducts. The biliary tree is morphologically and functionally heterogeneous. ${ }^{66,67}$ The bile produced by hepatocytes is initially secreted into the bile canaliculi; these in turn are connected with bile ducts through the interposition of Hering canals, narrow tubular channels lined in part by hepatocytes and in part by cholangiocytes that further modify the composition of bile..$^{68,69}$ Hering canals thus represent the anatomical and physiologic link between hepatocyte canaliculi and biliary ducts. They are in direct flow with small bile ducts (lined by cuboidal cells) that in turn empty into large bile ducts (lined by columnar cells). Cholangiocytes play an important role in water and electrolyte secretion, modulating canalicular bile through a sequence of both secretory and absorptive processes aimed at adjusting bile flow and alkalinity to the physio-
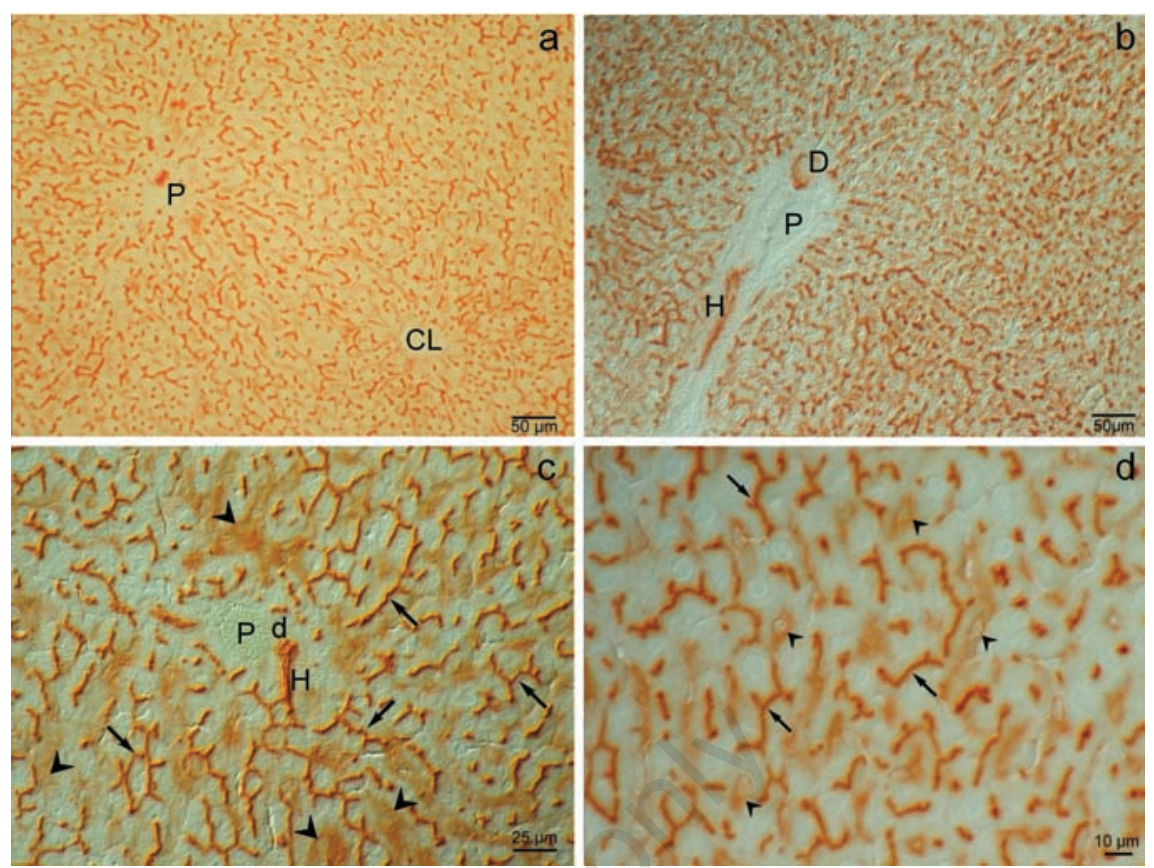

Figure 1. Wistar rat liver. Enzyme activity of DPP-IV: a) Survey view under low magnification of an wide area of liver parenchyma; the reaction is very intense in canaliculi from the portal to the centrolobular zone; brightfield. b) Besides in canaliculi the reaction is also present in a Hering canal $(\mathrm{H})$ and a bile duct (D); differential interference contrast. c) Particular of anastomotic network of branched channels and of hexagonal profiles restricted to regions between adjacent cells, representing the typical chicken-wire pattern of bile canaliculi (arrows); the reaction is furthermore present, though less intense, in sinusoidal endothelial cells (arrowhead) in the portal zone; a Hering canal (H) and a small bile duct (d) are also apparent; differential interference contrast. d) Details, under higher magnification, of the reaction in bile canaliculi (arrows) and in sinusoidal endothelial cells (arrowhead); differential interference contrast. $P$, portal vein; $C L$, centrolobular vein.

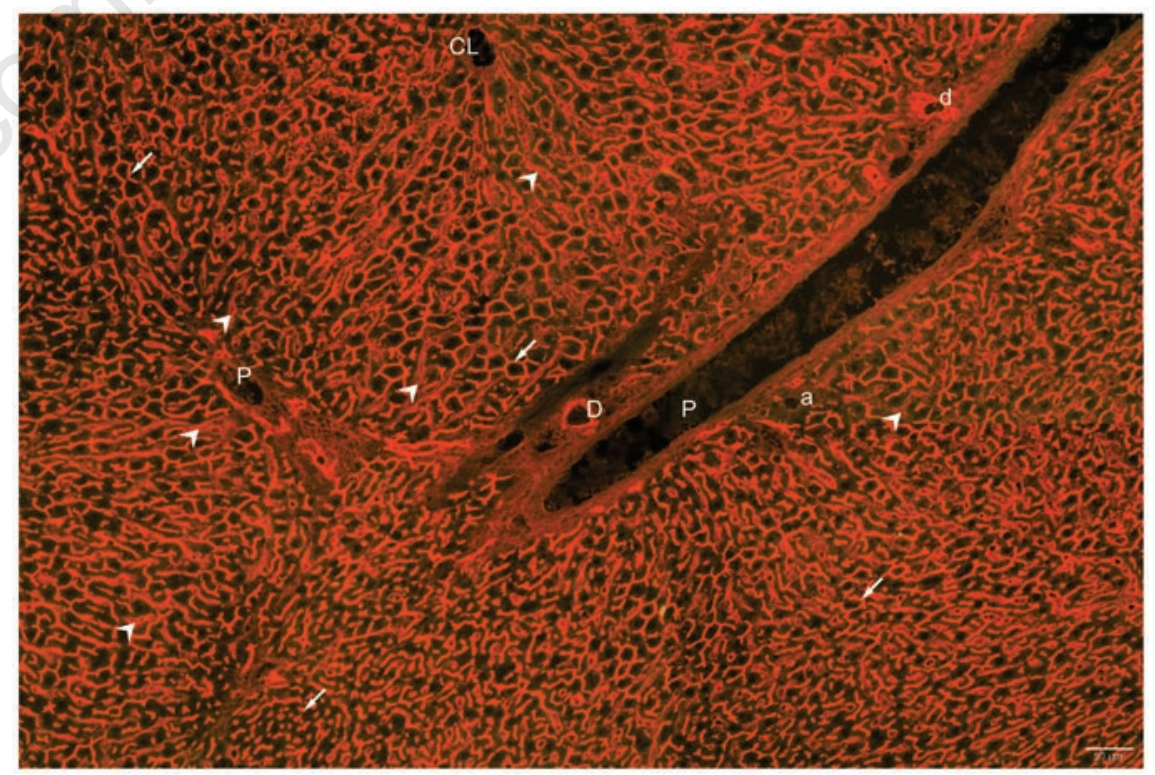

Figure 2. Demonstration of the expression of DPP-IV in Wistar rat liver by immunofluorescence. Immunopositivity, revealed by orange-red fluorescence, is present in the canalicular domain of hepatocytes in all lobular zones (white arrows) and in bile ducts (D). Less intense reactivity is also seen in sinusoidal endothelial cells (white arrow heads). Excitation of fluorescence with the triple filter also excites greenish tissue autofluorescence. 
logical needs. ${ }^{69-72}$ Hering canals and bile ducts, are believed to harbour hepatic stem cell niches. ${ }^{73,74}$ Hepatic progenitor cells are bi-potential stem cells residing in human and animal livers that are able to differentiate into the hepatocytic and the cholangiocytic lineages in stress situations that inhibit proliferation of hepatocytes and/or cholangiocytes. ${ }^{72}$ Cholangiocyte pathophysiology is regulated by several hormones, neuropeptides and neurotransmitters. ${ }^{75}$ Furthermore, liver progenitor cells are believed to form a neuroendocrine compartment under the control of the central nervous system. ${ }^{67}$

Biliary complications are considered the Achille's heel of liver transplantation because of their frequency and potential lethal effect on the survival of both graft and patients. ${ }^{3-7,17}$ Steatotic liver, increasingly frequent among potential liver grafts for OLT, is often discarded since its response to conventional cold storage is very poor. ${ }^{6,17}$ To investigate the behaviour of the various regions of the biliary tree of fatty livers in response to the stresses of transplantation a reliable marker was sought. In the present investigation we show that Dipeptidylpeptidase IV (DPP-IV) is expressed and catalytically active in the whole biliary tree of fatty liver, although the subcellular distribution sites in steatotic hepatocytes are altered respect to normal liver.

The patterns of enzyme activity, demonstrated with the azo-coupling method, and of protein expression, demonstrated by immunofluorescence with a monoclonal antibody against rat DPP-IV/CD26 (5E8 clone), on frozen sections submitted to the same fixation, were similar for all three animal models considered.

As a matter of fact, a DPP-IV-like enzyme activity (as revealed with the same azo-coupling histochemical method used in our research) is inherent to several molecular species, designed as DPP-IV Activity and/or Structure Homologs (DASH). ${ }^{76,77}$ The DASH family includes not only the prototype DPPIV/CD26 but also the Fibroblast activation protein 1a (FAP-1a), DPP6, DPP8, DPP9, seprase, attractin, $\mathrm{N}$-acetylated- $\alpha$-linked-acidic dipeptidases I, II and L, quiescent cell proline dipeptidase, thymus-specific serine protease and DPP-IVb. ${ }^{76}$ The DASH members share the unique capacity to process oligopeptides with proline or alanine at the penultimate position in their N-terminal, such as incretins, neuropeptides, chemokines, etc., modifying their biological activity, either through functional activation or inactivation, or else by facilitated degradation by other peptidases. Furthermore, they may be recognized by a different signalling receptor or convert the substrate into a receptor antagonist. ${ }^{76}$ Such behaviour has been particularly investigated in tumors, since the proliferation and migration of tumor,

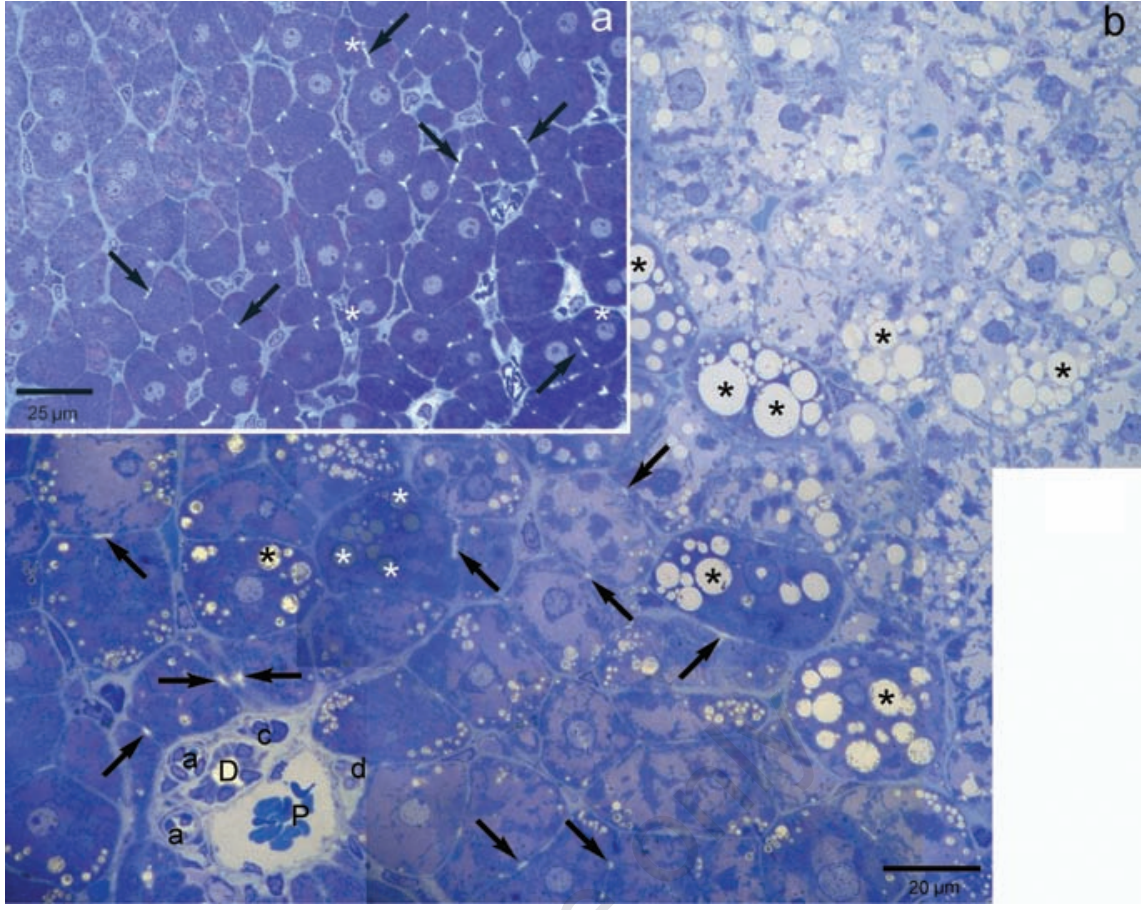

Figure 3. Representative light photographs of semi-thin sections of lean and obese Zucker rat liver stained with Toluidine Blue. a) Lean Zucker rat liver shows a normal morphology with almost lipid-free hepatocytes, rich in glycogen stores (magenta staining) and mitochondria; bile canaliculi (arrows) show regular distribution; when present (in hepatocytes and in stellate cells) lipid droplets are stained in dark blue (white asterisks), due to unsaturated lipids fixed by $\mathrm{OsO}_{4}$. b) In obese Zucker rat liver, bile canaliculi (arrows) are easily identified only in periportal hepatocytes (also characterized by the large magenta-stained areas correspondent to glycogen stores); by contrast, canaliculi are not visible in the steatotic areas where they are likely hidden or distorted by lipid droplets; both microsteatotic and macrosteatotic hepatocytes can be identified; most macrosteatotic hepatocytes show unstained lipid droplets (black asterisks) presumed to be of saturated lipid unfixed by $\mathrm{OsO}_{4}$; a few droplets of unsaturated lipids can also be observed (white asterisks). Brightfield: $P$, portal vein; D, bile duct; d, small bile duct; a, arteriole; c, capillary.

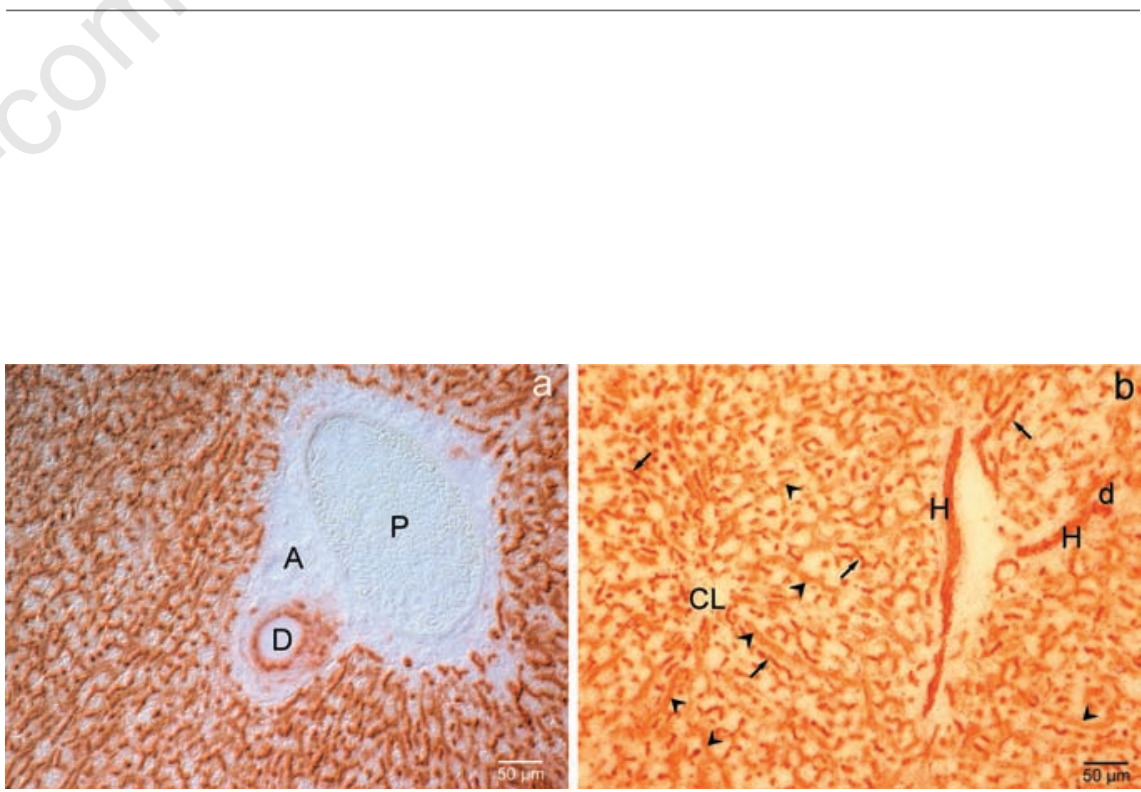

Figure 4. Lean Zucker rat liver. Enzyme activity of DPP-IV. a-b) DPP-IV enzyme activity is similar to that observed in the liver of Wistar rats, with intense positivity at bile canaliculi (arrows), Hering canals (H), small (d) and large (D) bile ducts level; sinusoidal cells (arrowheads) are also positive; A, artery. a) differential interference contrast; b) brightfield. P, portal vein; $C L$, centrolobular vein. 
inflammatory and stromal cells are conditioned by most members of the DASH family. ${ }^{78,79}$ In conclusion, the enzyme reaction would have detected the various DASH members whereas the immunoreaction would have demonstrated only DPP-IV. In our three models, however, the two reactions gave precisely the same patterns, suggesting that no inflammatory/fibrotic processes were going on.

In the following the DPP-IV catalytic/expression patterns in normal and fatty liver will be discussed in terms of the likely role of the protein in the various segments of the biliary tree and in sinusoidal cells.

\section{Wistar rat liver}

\section{Enzyme activity}

The patterns of DPP-IV activity in bile canaliculi, bile ducts and sinusoidal endothelial cells are in keeping with published data. ${ }^{32,80}$ The first papers describing canalicular activity of DPP-IV suggested that the protein was involved as an enzyme in the metabolism of substance $P$ and, as a ligand, in fibronectinmediated interactions of hepatocytes with the extracellular matrix. ${ }^{42,81,82}$

Substance $P$ and other possible substrates of DPP-IV are discussed in the following:

GLP-1 and GIP incretins. GLP-1 is secreted by enteroendocrine L cells and GIP by K cells of the intestine ${ }^{42}$ and stimulates insulin secretion by pancreatic $\beta$-cells. Signalling by GLP-1 and GIP is mediated through G-protein- coupled GLP-1 and GIP receptors (GLP-1R, GIP-R). One additional function of GLP-1, besides the regulation of glucose homeostasis, is the capacity of inducing transdifferentiation, that is the expression of neuroendocrine phenotype by pancreatic ductal cells, which share with cholangiocytes the embryonic origin, morphology, functional activity and response to injury. ${ }^{83}$ Liver cells were shown to be susceptible to the action of GLP-1 ${ }^{84,85}$ but only cholangiocytes were shown to express both the mRNA and protein for GLP-1R, which was upregulated in the course of cholestasis. ${ }^{86}$ GLP-1 is indeed a potent stimulator of cholangiocyte proliferation, and is required for the ductular reaction induced by cholestasis. ${ }^{86}$ As GIP is concerned, besides stimulating glucoseinduced insulin secretion, it also induces vasoconstriction or vasodilation depending on the vascular bed affected ${ }^{87}$ In particular, GIP is believed to maximize nutrient absorption by modulating portal blood flow. ${ }^{87}$ GIP has been reported to both increase hepatic portal venous flow and induce vasoconstriction of the hepatic artery, suggesting a direct vascular effect on liver vessels in response to meal ingestion, benefiting digestion and nutrient absorption. ${ }^{87}$ Receptors for GIP in the liver were found only in the endothelium of blood vessels. ${ }^{46,87-89}$
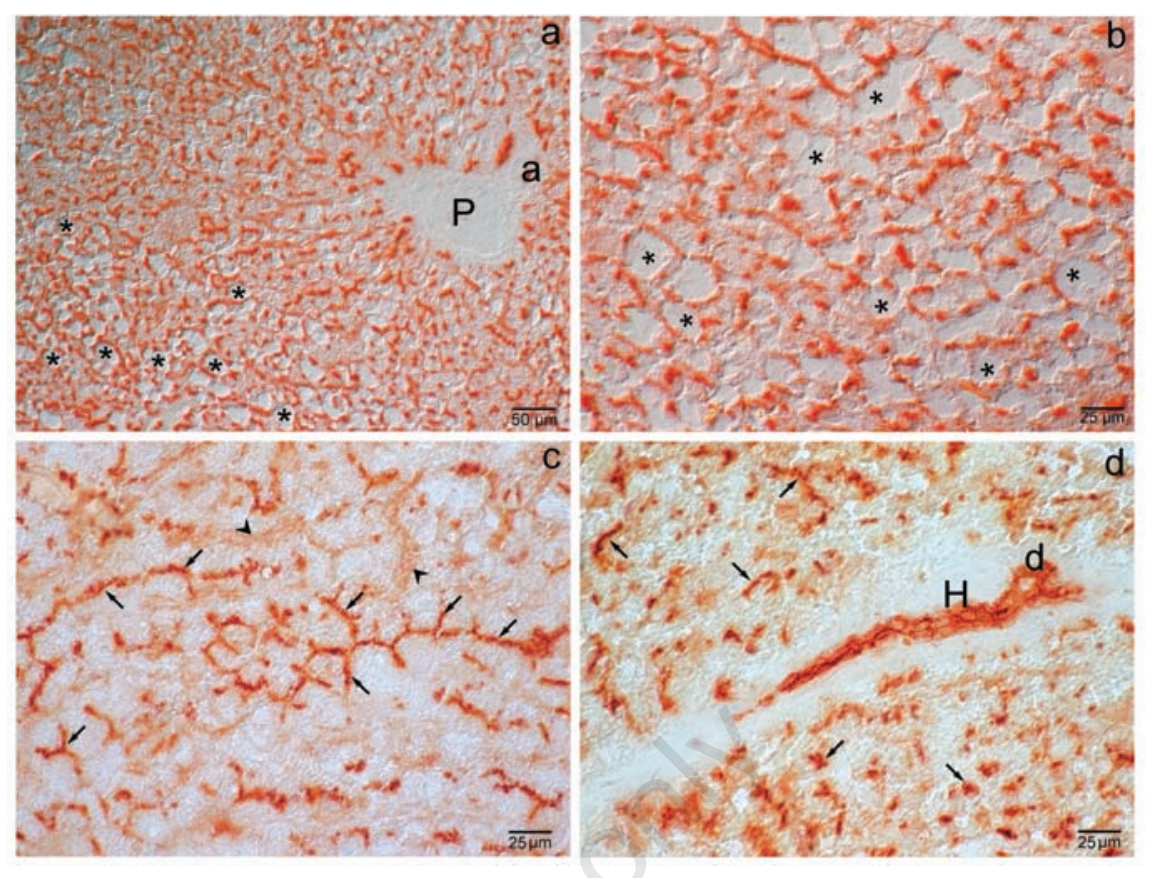

Figure 5. Obese Zucker rat liver. Enzyme activity. a) The patterns of DPP-IV activity in hepatocytes reflect the parenchymatic morphological alterations induced by steatosis (asterisks), especially in the mid-zone where the canalicular pattern has an irregular course and is displaced towards the cell periphery; differential interference contrast. b) Detail of enzyme activity in the highly steatosic hepatocytes (asterisks); differential interference contrast. c) Particular of the chicken-wire pattern of undistorted bile canaliculi (arrows); similarly to Wistar rat and lean ZR liver, moderate cytoplasmic enzyme activity is present in sinusoidal endothelial cells (arrowheads); brightfield. d) Enzyme activity in Hering canals $(\mathrm{H})$ and ducts (d); no activity is seen in the sinusoidal endothelial cells; brightfield. P, portal vein; a, arteriole.
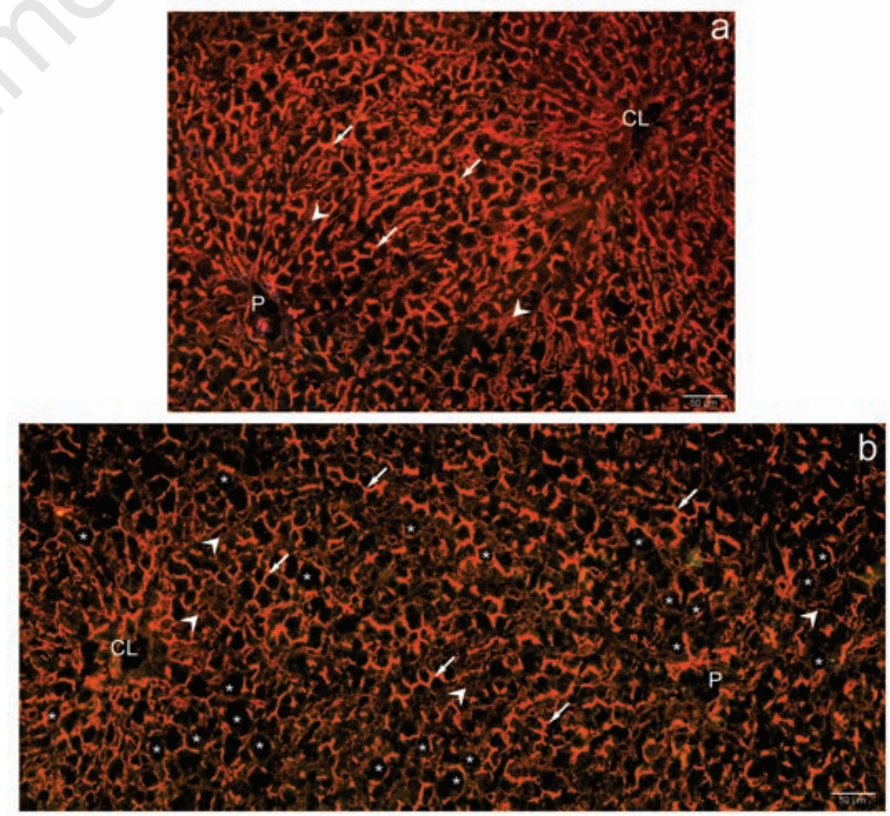

Figure 6. Demonstration of the expression of DPP-IV in lean and obese Zucker rat liver by immunofluorescence. Protein expression in lean Zucker rat liver (a) is similar to the patterns of enzyme activity in these animals (Figure 4). Also the expression of DPP-IV in obese rat liver (b) reflects the catalytic reaction (Figure 5), In particular, the marginalized expression of DPP-IV in hepatocytes of the mid-zone suggests either bile canaliculi deformed by lipid droplets (white asterisks) or else expression in the basolateral domains of hepatocytes; also low or null expression is observed in sinusoidal endothelial cells (white arrowheads). P, portal vein; CL, centrolobular vein; white arrows, bile canaliculi. 
Therefore GIP might be a substrate for the DPP-IV activity observed in the endothelium.

Neuropeptide $Y$ and substance P. DPP-IV-like activity splits an $\mathrm{N}$-terminal Tyr-Pro dipeptide from both NPY generating specific agonists for its receptor Y2. This has long-term consequences since by deactivating the signal transduction induced by the Y1 receptors, which favour proliferation, switching instead the response to that induced by Y2 receptors, that promote angiogenesis..$^{76} \mathrm{NPY}$ innervation was documented in the liver of various animals, including rat and humans, forming a network in Glisson's sheath and distributing around the walls of the interlobular portal vein, interlobular hepatic artery and hepatic bile duct. ${ }^{75,90,91}$ The presence of NPY-containing fibres distributed around the interlobular bile ducts implies that NPY is involved in the regulation of bile transport. The autonomic fibres that innervate the liver release, besides catecholamines and acetylcholine and the already cited NPY, other neuropeptides such as VIP and substance P that are potential DPP-IV substrates. ${ }^{75,92-95} \mathrm{NPY}$ is present in endothelial cells where it co-localizes with DPP-IV. ${ }^{76}$

Bombesin. The neuropeptide bombesin (gastrin-releasing peptide, GRP), through specific receptors, directly stimulates biliary bicarbonate and fluid secretion in the rat, mainly acting at the level of cholangiocytes. ${ }^{96}$ This stimulation is mediated by activation of the $\mathrm{Cl}^{-} / \mathrm{HCO}^{3}$ - exchange activity in cholangiocytes. ${ }^{96}$

Vasoactive intestinal peptide. VIP acts primarily at the level of bile ducts. In fact in vitro it has been found to have a stronger choleretic effect than bombesin and secretin (a further DPP-IV substrate). ${ }^{92}$ VIP is a potent stimulant of fluid and bicarbonate secretion from cholangiocytes via cAMP-independent pathways, suggesting that this neuropeptide plays a major regulatory role in biliary transport and secretion. ${ }^{92}$ The effects of VIP are mediated by the Gprotein coupled receptors VIPR1 e VIPR2 ${ }^{94,95}$ VIP-ergic nerve endings have been demonstrated in the portal tracts in close contact with hepatic arteries, portal veins and bile ducts. ${ }^{97}$ VIP and its receptors have also been shown to be involved in the effect of parasympathetic nerve activity on regeneration, and, in particular, on the proliferation of hepatic progenitor cells (HPC).$^{93}$ Expression of VIPR2 protein, but not of VIPR1, was detected in human HPCs in normal and diseased livers; VIPR2 mRNA was detected in rat HPCs. ${ }^{93}$ DPP-IV in biliary structures would thus contribute to the fading of the response elicited by these neurotransmitters.

Growth Hormone Releasing Hormone. GHRH released from the hypothalamus, increases $\mathrm{GH}$ secretion and synthesis in the hypophysis and subsequently stimulates, mainly in the liver, the production of insulin-like growth factor 1
(IGF-1) that controls cell growth. ${ }^{47}$ DPP-IV rapidly degrades GHRH in plasma and the DASH family is believed to be an important modulator of GHRH biological activity. ${ }^{76}$

Glucagon-like peptide-2. GLP-2 is a peptide hormone with multiple effects on the intestine, including expansion of the mucosal surface area through stimulation of crypt cell proliferation and enhancement of nutrient digestion and absorption. ${ }^{98}$ GLP-2 and GLP-1 can be metabolized locally but also in the circulation and in the liver by DPP-IV which inactivates them. ${ }^{99,100}$

Therefore, an important catalytic role of DPP-IV could be the degradation or the modulation of the activity incretins and neuropeptides in the biliary tract and in sinusoidal endothelial cells. ${ }^{42,47}$

Besides the roles as an enzyme, the protein DPP-IV also acts as a ligand. In particular, it is believed to be involved in the interactions, mediated by fibronectin, of hepatocytes with the extracellular matrix. ${ }^{82,101,102}$ Fibronectin is present not only in the inter-hepatocyte surfaces and the space of Disse, but also lining microvilli of bile canaliculi. ${ }^{103} \mathrm{~A}$ further known DPP-IV ligand is adenosine deaminase (ADA). In humans, binding of DPP-IV to ADA regulates the concentration of adenosine, an important regulator of cellular proliferation, at the cell surface and its intracellular levels. ${ }^{104}$ The contribution of DPP-IV together with its capacity to bind ADA in bile canaliculi were presumed to contribute to the regulation of adenosine levels in hepatocytes. ${ }^{104}$ However, the association of DPP-IV with ADA apparently does not occur in rats due to differences in the amino acid sequences involved in the binding. ${ }^{105,106}$

A further, and potentially important role of the protein, could be the modulation of $\mathrm{Na}^{+} / \mathrm{H}^{+}$ exchangers (NHE) activity, which play key roles both in acid-base balance and in fluid absorption in a number of epithelia. ${ }^{107}$ As a matter of fact, the isoform NHE3 was shown to exist in physical complexes with DPP-IV in the brush-border membranes isolated from proximal tubule cells ${ }^{51}$ and DPP-IV specific competitive inhibitors showed to reduce NHE3 activity in opossum kidney proximal tubule (OKP) cells, implying that DPP-IV activity modulated NHE3 activity in these cells. ${ }^{51}$ Similar findings were obtained in rat renal proximal tubule in vivo..$^{51}$ In the liver the NHE3 isoform is present in biliary canaliculi and cholangiocytes playing a functional role in fluid absorption. ${ }^{108}$ Therefore, DPP-IV might contribute to the regulation of bile $\mathrm{pH}$ by degrading bombesin and/or by interacting with NHE3.

In conclusion, DPP-IV in the normal liver appears to play key roles in the regulation of signalling by hormones controlling carbohydrate metabolism and by neurohormones. The presence of the enzyme in the biliary tree indi- cates that the clearance of such molecules is done preferentially through the biliary pathway, circumscribing the effects of these peptides to the gastro-enteric tract.

\section{Lean Zucker rats}

The catalytic/immunofluorescence patterns were similar to those obtained with Wistar rats and thus the same discussion applies to these animals.

\section{Obese Zucker rats}

Whereas in normal hepatocytes of the periportal region the activity/expression of DPP-IV patterns were similar to those of Wistar and lean Zucker rats, in the mid-zone and pericentral areas, where the hepatocytes were bloated with fat, the distribution of reaction product was clearly modified respect to normality and the typical chicken-wire pattern of bile canaliculi was not seen. Instead, the reaction, less intense, was concentrated apparently in marginal regions of hepatocytes that could be interpreted either as bile canaliculi deformed by the lipid droplets or else by redistribution of the protein to the baso-lateral domains of hepatocytes. It is worth recalling that the steatotic hepatocytes have much larger dimensions than normal cells and thus the $8 \mu \mathrm{m} \mathrm{sec}-$ tions used for the histochemical determinations might not reflect the real 3-dimensional canalicular network. Redistribution of DPP-IV to the basolateral domains of hepatocytes has been reported in several liver injuries and, in particular, in cirrhotic liver and in liver graft rejection. ${ }^{102,104}$ The redistribution of DPP-IV to the basolateral domains has been ascribed to the need of interaction with the extracellular matrix. ${ }^{102}$ A similar delocalization of normally canalicular enzyme activity, typical of cholestasis, was reported by our group for Alkaline Phosphatase activity. ${ }^{24}$ Several studies have demonstrated that obese Zucker rats present a marked reduction of bile salt-dependent and bile salt-independent bile flow typical of moderate cholestasis. ${ }^{109,110}$ These observations suggest that the bile canaliculi of steatotic hepatocytes in this animal model of obesity and insulin-resistance have a reduced capacity to inactivate or modify the activity of incretins and/or neuropeptides involved in the synthesis of insulin and/or in the control of appetite. Furthermore, scission by DPP-IV of neuropeptide YY (1-36), that regulates the sense of satiety, causes the formation of a biologically active truncated peptide (3-36) which promotes anorexia. ${ }^{111}$ It is currently believed that an altered regulation of incretins and neuropeptides plays an important role in the pathogenesis of obesity and insulin-resistance. ${ }^{54}$ In particular, DPP-IV should play a role in the progression of non-alcoholic fatty liver 
disease (NAFLD) as its mRNA is significantly higher in NAFLD patients than in control subjects. ${ }^{40}$

Since no alteration in enzyme activity/ expression was found in the upper segments of the biliary tree of obese respect to lean Zucker rats and Wistar rats, it can be presumed that obesity does not influence the behaviour of the protein in these segments of the biliary tree.

In conclusion, this research demonstrates that DPP-IV can be used as a marker of the whole biliary tree, not only in normal but also in fatty rats. This analysis, initially designed as a starting point to investigate the behaviour of fatty liver during the various phases of transplantation, appears to have a much higher potentiality as it could be further exploited to investigate any pathological or stressful conditions involving the biliary tract and its response to therapy. Examples of pathologies could be metabolic diseases, cirrhosis, biliary atresia, hepatocellular carcinoma and cholangiocarcinoma. A similar analysis could also be useful to follow the efficacy of DPP-IV inhibiting drugs in the treatment of obesity and insulin-resistance. Furthermore, and given that often NAFLD progresses to NASH and hepatocarcinoma it should be recalled that also collagen (which contains abundant X(OH)Pro-Gly sequences) is a potential DPP-IV substrate. ${ }^{112-114}$ DPP-IV activity/expression in activated fibroblasts and/or stellate cells and resting and especially activated T cells ${ }^{114}$ of fibrotic/cirrhotic livers thus deserve to be evaluated. Of particular interest could also be investigating whether liver progenitor cells, presumed to be derived from Hering canals, ${ }^{93}$ express DPP-IV. And finally, it is worth recalling that DPP-IV was shown to play an important role in the progression of a wide spectrum of malignancies. ${ }^{26}$ Loss or alteration of DPP-IV has been observed in hepatocellular carcinoma. ${ }^{33}$ The development of therapeutic modalities targeting DPP-IV was proposed as a strategy in the treatment of selected tumors. ${ }^{24}$ Thus, the demonstration of DPP-IV activity/expression in the various microenvironments of liver malignancies might provide interesting information.

\section{References}

1. Sun B, Jiang HC, Piao DX, Qiao HQ, Zhang L. Effects of cold preservation and warm reperfusion on rat fatty liver. World J Gastroenterol 2000;6:271-4.

2. Angele MK, Rentsch M, Hartl WH, Wittmann B, Graeb C, Jauch KW, et al. (Effect of graft steatosis on liver function and organ survival after liver transplantation. Am J Surg 2008;195:214-20.
3. Fukumori T, Ohkohchi N, Tsukamoto S, Satomi S. The mechanism of injury in a steatotic liver graft during cold preservation. Transplantation 1999;67:195-200.

4. Burke A, Lucey MR. Non-alcoholic fatty liver disease, non-alcoholic steatohepatitis and orthotopic liver transplantation. Am J Transplant 2004;4:686-93.

5. Marsman H, Matsushita T, Dierkhising R, Kremers W, Rosen C, Burgart L, et al. Assessment of donor liver steatosis: pathologist or automated software? Hum Pathol 2004;35:430-5.

6. Dutkowski P, de Rougemont 0, Clavien PA. Machine perfusion for 'marginal' liver grafts. Am J Transplant 2008;8:917-24.

7. Attia M, Silva MA, Mirza DF. The marginal liver donor - an update. Transpl Int 2008;21:713-24.

8. Baccarani U, Adani GL, Isola M, Avellini C, Lorenzin D, Rossetto A, et al. Steatosis of the graft is a risk factor for posttransplantation biliary complications. Transplant Proc 2009;41:1313-5.

9. Krom RA, Sanchez-Urdazpal L. The biliary tree--the Achilles tendon of liver preservation? Transplantation 1992;53:1167.

10. Buis CI, Hoekstra H, Verdonk RC, Porte RJ. Causes and consequences of ischemic-type biliary lesions after liver transplantation. J Hepatobiliary Pancreat Surg 2006;13:517-24.

11. Koneru B, Sterling MJ, Bahramipour PF. Bile duct strictures after liver transplantation: a changing landscape of the Achilles' heel. Liver Transpl 2006;12:7024.

12. Roma MG, Sanchez Pozzi EJ. Oxidative stress: a radical way to stop making bile. Ann Hepatol 2008;7:16-33.

13. Heidenhain C, Pratschke J, Puhl G, Neumann U, Pascher A, Veltzke-Schlieker $\mathrm{W}$, et al. Incidence of and risk factors for ischemic-type biliary lesions following orthotopic liver transplantation. Transpl Int 2010;23:14-22.

14. Buis CI, Geuken E, Visser DS, Kuipers F, Haagsma EB, Verkade HJ, et al. Altered bile composition after liver transplantation is associated with the development of nonanastomotic biliary strictures. J Hepatol 2009;50:69-79.

15. Lenzen R, Bähr A, Eichstädt H, Marschall U, Bechstein WO, Neuhaus P. In liver transplantation, $\mathrm{T}$ tube bile represents total bile flow: physiological and scintigraphic studies on biliary secretion of organic anions. Liver Transpl Surg 1999; 5:8-15.

16. Cutrin JC, Cantino D, Biasi F, Chiarpotto E, Salizzoni M, Andorno E, et al. Reperfusion damage to the bile canaliculi in transplanted human liver. Hepatology
1996;24:1053-7.

17. Kukan M, Haddad PS. Role of hepatocytes and bile duct cells in preservation/ reperfusion injury of liver grafts. Liver Transplant 2001;7:381-400.

18. Testa G, Malagò M, Broelseh CE. Complications of biliary tract in liver transplantation. World J Surg 2001;25: 1296-9.

19. Vairetti M, Ferrigno A, Rizzo V, Boncompagni E, Carraro A, Gringeri E, et al. Correlation between the liver temperature employed during machine perfusion and reperfusion damage: role of $\mathrm{Ca}^{+}$. Liver Transpl 2008;14:494-503.

20. Vairetti M, Ferrigno A, Carlucci F, Tabucchi A, Rizzo V, Boncompagni E, et al. Subnormothermic machine perfusion protects steatotic livers against preservation injury: a potential for donor pool increase? Liver Transpl 2009;15:20-9.

21. Ferrigno A, Carlucci F, Tabucchi A, Tommassini V, Rizzo V, Richelmi P, et al. Different susceptibility of liver grafts from lean and obese Zucker rats to preservation injury. Cryobiology 2009;59:327-34.

22. Ferrigno A, Rizzo V, Boncompagni E, Bianchi A, Gringeri E, Neri D, et al. Machine perfusion at $20^{\circ} \mathrm{C}$ reduces preservation damage to livers from nonheart beating donors. Cryobiology 2011;62:152-8.

23. Boncompagni E, Gini E, Ferrigno A, Milanesi G, Gringeri E, Barni S, et al. Decreased apoptosis in fatty livers submitted to subnormothermic machine-perfusion respect to cold storage. Eur J Histochem 2011;55:e40.

24. Bertone V, Tarantola E, Ferrigno A, Gringeri E, Barni S, Vairetti M, et al. Altered alkaline phosphatase activity in the liver of obese Zucker rats respect to lean Zucker and Wistar rats discussed in terms of all putative roles ascribed to the enzyme. Eur J Histochem 2011;55:e5.

25. Chen X. Biochemical properties of recombinant prolyl dipeptidases DPP-IV and DPP8. Adv Exp Med Biol 2006;575:27-32.

26. Pro B, Dang NH. CD26/dipeptidyl peptidase IV and its role in cancer. Histol Histopathol 2004;19:1345-51.

27. Ohnuma K, Takahashi N, Yamochi T, Hosono 0, Dang NH, Morimoto C. Role of CD26/dipeptidyl peptidase IV in human T cell activation and function. Front Biosci 2008;13:2299-310.

28. Ohnuma K, Hosono 0, Dang $\mathrm{NH}$, Morimoto C. Dipeptidyl peptidase in autoimmune pathophysiology. Adv Clin Chem 2011;53:51-84.

29. Hartel S, Gossrau R, Hanski C, Reutter W. Dipeptidyl peptidase (DPP) IV in rat 
organs. Comparison of immunohistochemistry and activity histochemistry. Histochemistry. 1988;89:151-161.

30. Ruhnke M, Gossrau R. Reaction rate measurements of proteases and glycosidases with chromogenic methods. Histochem J 1989;21:535-44.

31. Hartel-Schenk S, Gossrau R, Reutter W. Comparative immunohistochemistry and histochemistry of dipeptidyl peptidase IV in rat organs during development. Histochem J 1990;22:567-78.

32. Lojda Z, Gossrau R, Stoward PJ. Proteases. In: PJ Stoward and AG Everson Pearse (eds.) Histochemistry, Vol III (Fourth Edition). Edinburgh, Churchill Livingstone, 1991, pp. 281-335.

33. Stecca BA, Nardo B, Chieco P, Mazziotti A, Bolondi L, Cavallari A. Aberrant dipeptidyl peptidase IV (DPP IV/CD26) expression in human hepatocellular carcinoma. J Hepatol 1997;27:337-45.

34. Gorrell MD. Dipeptidyl peptidase IV and related enzymes in cell biology and liver disorders. Clin Sci 2005;108:1-16.

35. Chyan YJ, Chuang LM. Dipeptidyl peptidase-IV Inhibitors: an evolving treatment for type 2 diabetes from the incretin concept. Recent patents on endocrine, metabolic \& immune drug discovery 2007;1:1524. http://www.benthamscience.com/ emi/samples/emi1-1/Chuang.pdf

36. DiStefano JK, Watanabe RM. Pharmacogenetics of anti-diabetes drugs. Pharmaceuticals 2010;3:2610-46.

37. Addison D, Aguilar D. Diabetes and cardiovascular disease: the potential benefit of incretin-based therapies. Curr Atheroscler Rep 2011;13:115-22.

38. Schuppan D, Gorrell MD, Klein T, Mark M, Afdhal NH. The challenge of developing novel pharmacological therapies for nonalcoholic steatohepatitis. Liver In. 2010;30:795-808.

39. Shirakawa J, Fujii H, Ohnuma K, Sato K, Ito Y, Kaji M, et al. Diet-induced adipose tissue inflammation and liver steatosis are prevented by DPP-4 inhibition in diabetic mice. Diabetes 2011;60:1246-57.

40. Miyazaki M, Kato M, Tanaka K, Tanaka M, Kohjima M, Nakamura K, et al. Increased hepatic expression of dipeptidyl peptidase-4 in non-alcoholic fatty liver disease and its association with insulin resistance and glucose metabolism. Mol Med Report 2012;5:729-33.

41. Vanhoof G, Goossens F, De Meester I, Hendriks D, Scharpé S. Proline motifs in peptides and their biological processing. FASEB J 1995; 9:736-44.

42. Mentlein R. Dipeptidyl-peptidase IV (CD26)-role in the inactivation of regulatory peptides. Regulatory Peptides 1999;
85:9-24.

43. Hildebrandt M, Reutter W, Arck P, Rose M, Klapp BF. A guardian angel: the involvement of dipeptidyl peptidase IV in psychoneuroendocrine function, nutrition and immune defence. Clin Sci (Lond) 2000;99:93-104.

44. Boonacker E, Van Noorden CJF. The multifunctional or moonlighting protein CD26/DPPIV. Eur J Cell Biol 2003;82:5373.

45. McIntosh CH, Demuth HU, Kim SJ, Pospisilik JA, Pederson RA. Applications of dipeptidyl peptidase IV inhibitors in diabetes mellitus. Int J Biochem Cell Biol 2006;38:860-872.

46. Flatt PR. Dorothy Hodgkin Lecture 2008. Gastric inhibitory polypeptide (GIP) revisited: a new therapeutic target for obesitydiabetes? Diabet Med 2008;25:759-64.

47. Mentlein R. Mechanisms underlying the rapid degradation and elimination of the incretin hormones GLP-1 and GIP. Best Pract Res Clin Endocrinol Metab 2009; 4:443-52

48. Thulesen J, Hartmann B, Orskov C, Jeppesen PB, Holst JJ, Poulsen SS. Potential targets for glucagon-like peptide 2 (GLP-2) in the rat: distribution and binding of i.v. injected (125)I-GLP-2. Peptides 2000;21:1511-7.

49. Cheng HC, Abdel-Ghany M, Elble RC, Pauli BU. Lung endothelial dipeptidyl peptidase IV promotes adhesion and metastasis of rat breast cancer cells via tumor cell surface-associated fibronectin. J Biol Chem 1998;273:24207-15.

50. Balaban YH, Korkusuz P, Simsek H, Gokcan H, Gedikoglu G, Pinar A, et al. Dipeptidyl peptidase IV (DDP IV) in NASH patients. Ann Hepatol 2007;6:242-50.

51. Girardi AC, Fukuda LE, Rossoni LV, Malnic G, Rebouças NA. Dipeptidyl peptidase IV inhibition downregulates $\mathrm{Na}^{+}-\mathrm{H}^{+}$ exchanger NHE3 in rat renal proximal tubule. Am J Physiol Renal Physiol 2008;294: F414-22.

52. Jeffery CJ. Moonlighting proteins. Trends Biochem Sci 1999;24:8-11.

53. Ejiri S. Moonlighting functions of polypeptide elongation factor 1: from actin bundling to zinc finger protein R1associated nuclear localization. Biosci Biotechnol Biochem 2002;66:1-21.

54. Kesty NC, Roth JD, Maggs D. Hormonebased therapies in the regulation of fuel metabolism and body weight. Expert Opin Biol Ther 2008;8:1733-47.

55. Yip RG, Wolfe MM. GIP biology and fat metabolism. Life Sci. 2000;66:91-103.

56. Nielsen LL. Incretin mimetics and DPP-IV inhibitors for the treatment of type 2 diabetes. Drug Discov Today 2005;10:703-10.
57. Brubaker PL, Drucker DJ. Minireview: Glucagon-like peptides regulate cell proliferation and apoptosis in the pancreas, gut, and central nervous system. Endocrinology 2004;145:2653-9.

58. Seifalian AM, Piasecki C, Agarwal A, Davidson BR. The effect of graded steatosis on flow in the hepatic parenchymal microcirculation. Transplantation 1999; 68:780-4.

59. Sun CK, Zhang XY, Zimmermann A, Wheatley AM. The metabolic and microcirculatory impact of orthotopic liver transplantation on the obese Zucker rat. Transplantation 2003;75:761-9.

60. Chen D, Wang MW. Development and application of rodent models for type 2 diabetes. Diabetes Obes Metab 2005; 7:307-17.

61. Aleixandre de Artiñano A, Miguel Castro M. Experimental rat models to study the metabolic syndrome. Br J Nutr 2009; 102:1246-53.

62. Koteish A, Diehl AM. Animal models of steatosis. Semin Liver Dis 2001;21:89104.

63. Van Noorden CJF, Fredericks WM. Enzyme histochemistry: a laboratory manual of current methods. 0xford, 0xford University Press, Royal Microscopy Society, 1992, pp. 68-70.

64. Rose S. Gastrointestinal and hepatobiliary pathophysiology. Madison, USA, Fence Creek Publishing, 1998, pp. 80,123134.

65. Zsembery A, Thalhammer T, Graf J. Bile formation: a concerted action of membrane transporters in hepatocytes and cholangiocytes. News Physiol Sci 2000; 15:6-11.

66. Saxena R, Theise ND, Crawford JM. Microanatomy of the human liver-exploring the hidden interfaces. Hepatology 1999;30:1339-46.

67. Roskams TA, Theise ND, Balabaud C Bhagat G, Bhathal PS, Bioulac-Sage P, et al. Nomenclature of the finer branches of the biliary tree: canals, ductules, and ductular reactions in human livers. Hepatology 2004;39:1739-45.

68. Kanno N, LeSage G, Glaser S, Alvaro D Alpini G. Functional heterogeneity of the intrahepatic biliary epithelium. Hepatology. 2000;31:555-61.

69. Strazzabosco M, Fabris L. Functional anatomy of normal bile ducts. Anat Rec (Hoboken). 2008;291:653-60

70. Alpini G, Phillips J, La Russo N. The biology of biliary epithelia. In: IM Arias, JL Boyer, N Fausto, WB Jakoby, D Schachter and DA Shafritz (eds.) The liver: biology and pathobiology (3rd ed.) New York, USA, Raven press Ltd.,1994, pp. 623-653. 
71. Lazaridis KN, Strazzabosco M, Larusso NF. The cholangiopathies: disorders of biliary epithelia. Gastroenterology 2004;127:1565-77.

72. Gaudio E, Carpino G, Cardinale V, Franchitto A, Onori P, Alvaro D. New insights into liver stem cells. Dig Liver Dis 2009;41:455-62.

73. Kuwahara R, Kofman AV, Landis CS, Swenson ES, Barendswaard E, Theise ND. The hepatic stem cell niche: identification by label-retaining cell assay. Hepatology 2008;47:1994-2002.

74. Turner R, Lozoya 0, Wang Y, Cardinale V, Gaudio E, Alpini G, et al. Human hepatic stem cell and maturational liver lineage biology. Hepatology 2011;53:1035-45.

75. Marzioni M, Fava G, Benedetti A. Nervous and Neuroendocrine regulation of the pathophysiology of cholestasis and of biliary carcinogenesis. World J Gastroenterol 2006;12:3471-80.

76. Busek P, Malík R, Sedo A. Dipeptidyl peptidase IV activity and/or structure homologues (DASH) and their substrates in cancer. Int J Biochem Cell Biol 2004; $36: 408-21$.

77. Sedo A, Malik R. Dipeptidyl peptidase IVlike molecules: homologous proteins or homologous activities? Biochim Biophys Acta 2001;1550:107-16.

78. Busek P, Krepela E, Mares V, Vlasicova K, Sevcik J, Sedo A. Expression and function of dipeptidyl peptidase IV and related enzymes in cancer. Adv Exp Med Biol 2006;575:55-62.

79. Mares V, Stremenova J, Lisá V, Kozáková H, Marek J, Syrucek M, et al. Compart ment- and malignance-dependent up-regulation of -glutamyltranspeptidase and dipetidylpeptidase-IV activity in human brain gliomas. Histol Histopathol 2012; 27:931-40.

80. Gossrau R. Peptidases II. Localization of dipeptidylpeptidase IV (DPP IV). Histochemical and biochemical study. Histochemistry 1979;60:231-48.

81. Heymann E, Mentlein R. Liver dipeptidyl aminopeptidase IV hydrolyzes substance P. FEBS Letters 1978;91:360-4.

82. Ariyoshi M, Mizuno M, Morisue $\mathrm{Y}$, Shimada M, Fujita S, Nasu J, et al. Identification of a target antigen recognized by a mouse monoclonal antibody to the bile canalicular surface of rat hepatocytes with a random phage display library. Acta Med Okayama 2002;56:187-91.

83. Grapin-Botton A. Ductal cells of the pancreas. Int $\mathrm{J}$ Biochem Cell Biol 2005;37:504-10.

84. Lopez-Delgado MI, Morales M, VillanuevaPeñacarrillo ML, Malaisse WJ, Valverde I. Effects of glucagon-like peptide 1 on the kinetics of glycogen synthase a in hepatocytes from normal and diabetic rats. Endocrinology 1998;139:2811-7.

85. Redondo A, Trigo MV, Acitores A, Valverde I, Villanueva-Penacarrillo ML. Cell signalling of the GLP-1 action in rat liver. Mol Cell Endocrinol 2003;204:43-50.

86. Marzioni M, Alpini G, Saccomanno S, Candelaresi C, Venter J, Rychlicki C, et al. Glucagon-like peptide-1 and its receptor agonist exendin-4 modulate cholangiocyte adaptive response to cholestasis. Gastroenterology 2007;133:244-55.

87. Zhong Q, Bollag RJ, Dransfield DT, Gasalla-Herraiz J, Ding KH, Min L, Isales CM. Glucose-dependent insulinotropic peptide signaling pathways in endothelial cells. Peptides 2000; 21:1427-32.

88. Flatt PR, Bailey CJ, Green BD. Dipeptidyl peptidase IV (DPP IV) and related molecules in type 2 diabetes. Front Biosci 2008;13:3648-60.

89. Ding $\mathrm{KH}$, Zhong $\mathrm{Q}, \mathrm{Xu} \mathrm{J}$, Isales $\mathrm{CM}$. Glucose-dependent insulinotropic peptide: differential effects on hepatic artery vs. portal vein endothelial cells. Am J Physiol Endocrinol Metab 2004;286:E7739.

90. Ding WG, Kitasato H, Kimura H. Development of neuropeptide Y innervation in the liver. Microsc Res Tech 1997;39:365-71.

91. McCuskey RS. Anatomy of efferent hepatic nerves. Anat Rec A Discov Mol Cell Evol Biol 2004;280:821-6.

92. Cho WK, Boyer J. Vasoactive intestinal polypeptide is a potent regulator of bile secretion from rat cholangiocytes. Gastroenterology 1999;117:420-8.

93. Cassiman D, Sinelli N, Bockx I, Vander Borght S, Petersen B, De Vos R, et al. Human hepatic progenitor cells express vasoactive intestinal peptide receptor type 2 and receive nerve endings. Liver Int 2007;27:323-8.

94. Onoue S, Misaka S, Yamada S. Structureactivity relationship of vasoactive intestinal peptide (VIP): potent agonists and potential clinical applications. Naunyn Schmiedebergs Arch Pharmacol 2008; 377:579-90.

95. Moody TW, Ito T, Osefo N, Jensen RT. VIP and PACAP: recent insights into their functions/roles in physiology and disease from molecular and genetic studies. Curr Opin Endocrinol Diabetes Obes 2011; 18:61-7.

96. Cho WK. Role of the neuropeptide, bombesin, in bile secretion. Yale $\mathrm{J}$ Biol Med. 1997; 70:409-416.

97. Ueno T, Inuzuka S, Torimura T, Sakata R, Sakamoto M, Gondo K, et al. Distribution of substance $\mathrm{P}$ and vasoactive intestinal peptide in the human liver: light and electron immunoperoxidase methods of observation. Am J Gastroenterol 1991;86: 1633-7.

98. Rowland KJ, Brubaker PL. The "cryptic" mechanism of action of glucagon-like peptide-2. Am J Physiol Gastrointest Liver Physiol 2011;301:G1-8.

99. Holst JJ, Vilsbøll T, Deacon CF. The incretin system and its role in type 2 diabetes mellitus. Mol Cell Endocrinol 2009;297:127-36.

100. Holst JJ. Glucagon and glucagon-like peptides 1 and 2. Results Probl Cell Differ 2010;50:121-35.

101. Piazza GA, Callanan HM, Mowery J, Hixson DC. Evidence for a role of dipeptidyl peptidase IV in fibronectin-mediated interactions of hepatocytes with extracellular matrix. Biochem J 1989;262:327-4.

102. Matsumoto Y, Bishop GA, McCaughan GW. Altered zonal expression of the CD26 antigen (dipeptidyl peptidase IV) in human cirrhotic liver. Hepatology 1992;15:1048-53.

103. Stamatoglou SC, Ge RC, Mills G, Butters TD, Zaidi F, Hughes RC. Identification of a novel glycoprotein (AGp110) involved in interactions of rat liver parenchymal cells with fibronectin. J Cell Biol 1990;111: 2117-27.

104. McCaughan GW, Gorrell MD, Bishop GA, Abbott CA, Shackel NA, McGuinness PH, et al. Molecular pathogenesis of liver disease: an approach to hepatic inflammation, cirrhosis and liver transplant tolerance. Immunol Rev 2000;174:172-91.

105. Gorrell MD, Abbott CA, Kähne T, Levy MT, Church WB, McCaughan GW. Relating structure to function in the beta-propeller domain of dipeptidylpeptidase IV. Point mutations that influence adenosine deaminase binding, antibody binding and enzyme activity. In: J Langner and S Ansorge (eds.) Cellular peptidases in immune functions and diseases 2. New York, USA Kluwer Academic/Plenum Publishers, 2000, pp. 89-95.

106. Longenecker KL, Stewart KD, Madar DJ, Jakob CG, Fry EH, Wilk S, et al. Crystal structures of DPPIV (CD 26) from rat kidney exhibit flexible accommodation of peptidase-selective inhibitors. Biochemistry 2006;45:7474-82.

107. Orlowski J, Grinstein $\mathrm{S}$. $\mathrm{Na}^{+} / \mathrm{H}^{+}$exchangers of mammalian cells. J Biol Chem 1997;272:22373-6.

108. Mennone A, Biemesderfer D, Negoianu D, Yang CL, Abbiati T, Schultheis PJ, et al. Role of sodium/hydrogen exchanger isoform NHE3 in fluid secretion and absorption in mouse and rat cholangiocytes. Am J Physiol Gastrointest Liver Physiol 2001; 
280:G247-54.

109. Pizarro M, Balasubramaniyan N, Solís N, Solar A, Duarte I, Miquel JF, et al. Bile secretory function in the obese Zucker rat: evidence of cholestasis and altered canalicular transport function. Gut 2004;53:1837-43.

110. Geier A, Dietrich CG, Grote T, Beuers U, Prüfer T, Fraunberger $P$, et al. Characterization of organic anion transporter regulation, glutathione metabolism and bile formation in the obese
Zucker rat. J Hepatol 2005;43:1021-30.

111. Unniappan S, McIntosh CH, Demuth HU, Heiser U, Wolf R, Kieffer TJ. Effects of dipeptidyl peptidase IV on the satiety actions of peptide YY. Diabetologia 2006;49:1915-23.

112. Hong WJ, Petell JK, Swank D, Sanford J, Hixson DC, Doyle D. Expression of dipeptidyl peptidase IV in rat tissues is mainly regulated at the mRNA levels. Exp Cell Res 1989;182:256-6.

113. Wang XM, Yao TW, Nadvi NA, Osborne B,
McCaughan GW, Gorrell MD. Fibroblast activation protein and chronic liver disease. Front Biosci 2008;13:3168-80.

114. Keane FM, Chowdhury S, Yao T-W, Nadvi NA, Gall MG, Chen Y, et al. Targeting dipeptidyl peptidase-4 (DPP-4) and fibroblast activation protein (FAP) for diabetes and cancer therapy. In: B Dunn (ed.) RSC Drug Discovery Series No. 18. Proteinases as drug targets. Royal Society of Chemistry, 2012, pp. 119-145. 